\title{
SELF-EFFICACY, ORGANIZATIONAL COMMITMENT, AND EMPLOYEE PERFORMANCE - FROM PUBLIC OFFICE
}

\author{
Siti Maria ${ }^{1}$, Digra Lestari ${ }^{2 *}$, Eny Rochaida ${ }^{3}$, Dio Caisar Darma ${ }^{4}$, \\ Heni Rahayu Rahmawati ${ }^{5}$
}

\begin{abstract}
${ }^{1}$ Faculty of Economics and Business, Mulawarman University, Indonesia, siti.maria@feb.unmul.ac.id ${ }^{2}$ Faculty of Economics and Business, Mulawarman University, Indonesia, dirge.lestari@feb.unmul.ac.id

${ }^{3}$ Faculty of Economics and Business, Mulawarman University, Indonesia, eny.rochaida@feb.unmul.ac.id ${ }^{4}$ Department of Management, Sekolah Tinggi Ilmu Ekonomi Samarinda, Indonesia, diocaisar@stiesam.ac.id

${ }^{5}$ Faculty of Economics and Business, Mulawarman University, Indonesia, heni.rahayu.rahmawati@feb.unmul.ac.id
\end{abstract}

\begin{abstract}
Employee performance is important because it is the foundation and direction of every organization. In this paper, we attempt to investigate the effect of self-efficacy on organizational commitment and employee performance, then the effect of organizational commitment on employee performance. The objectivity of the study refers to 100 informant units obtained through a survey of employees in the Tourism and Culture Office of East Kalimantan Province, Indonesia. The sampling approach uses a saturated sample method with Structural Equation MedellingPartial Least Square (SEM-PLS). These findings indicate that self-efficacy has a significant effect on organizational commitment and employee performance. Similar to the previous results, organizational commitment has a significant effect on employee performance. With these findings, it can contribute to the role of a leader who must have optimal leadership characteristics, so that self-efficacy, organizational commitment, and employee performance continue to be optimal as expected.
\end{abstract}

Keywords:

HRM, Civil servants, Public office, Survey, SEM-PLS

JEL Classification: M12, D73, C83, C36

DOI: $10.24818 / \mathrm{CTS} / 3 / 2021 / 1.01$

\section{Introduction}

Civil servants (PNS) as elements of the state apparatus are tasked with providing services to the community in a professional, honest, fair, equitable manner, implementing state, government, and development tasks (Zainurossalamia et al., 2020). The realization of a clean and authoritative government begins with the enforcement of national discipline within the state apparatus, especially civil servants. According to Purwadi et al. (2020) Civil servants in Indonesia generally still do not comply with disciplinary regulations, so that they can hamper the smooth functioning of government and national development.

As an effort to improve civil servant discipline, the Indonesian government has made a regulation contained in Government Regulation of the Republic of Indonesia Number 53 of 2010. They as government officials and public servants are expected to always be ready to carry out tasks that have become their responsibility properly, but the reality often occurs in a government agency, often commits violations, and can lead to sub-optimal performance (Darma et al., 2020).

Increased competition, challenges, and demands from the community for excellent service have encouraged the East Kalimantan Public Works and Public Housing Service to prepare themselves to continue to exist and be superior to constantly strive for changes towards improvement, especially in terms of employee performance. This transformation is carried out in stages, planned, consistently, and

\footnotetext{
* Contact author
} 
sustainably so as to increase the accountability of agency performance which is oriented towards achieving results and benefits for the optimization of employee performance (e.g. Faradila et al., 2020; Maria et al., 2020; Wijayanti et al., 2020).

Self-efficacy is needed by employees to improve their abilities according to the job desk given by their superiors so that the organization runs optimally and employee job satisfaction will increase (Bandura, 2006). Therefore, the role of self-efficacy is needed so that they can work well and have high job satisfaction.

The higher the employee's self-efficacy, the more persistent the effort is made, the latest studies by Sarinah et al. (2018) and Zeb \& Nawaz (2016) prove that self-efficacy can improve a person's quality and psychosocial. Good self-efficacy has a major contribution to individual motivation. This includes, among other things, how the individual formulates goals or targets for himself, the extent to which the individual fights for that target, and how tough the individual can face failure. Thus, self-efficacy can affect how they think, feel, motivate themselves, and act according to the rules, so that in the end it will create organizational commitment and employee performance (Yokoyama, 2019; Issa, 2016).

Employees with high organizational commitment have different attitudes than those with low commitment. High organizational commitment results in work performance, low levels of absences, and low levels of achievement of employee work targets. In addition, those who are highly committed will have maximum work performance (Dinc, 2017).

The problem that occurs in the Tourism and Culture Office of East Kalimantan Province is the lack of awareness of employees to be able to give their best performance in order to improve overall performance. This can be seen through the lack of awareness of employees in completing work maximally that is not on time with the targets set by the agency and work programs that should be run have delayed schedules, so that job evaluation cannot be carried out either. The preliminary observations we have explored suggest that most of them do not yet have complete self-efficacy in getting the job done. They assume that the work will be completed if there are other employees who help. Not achieving job targets makes them less committed to the work they are currently doing and have no commitment to the organization.

The focus of this study is to understand the effect of self-efficacy on organizational commitment and employee performance, and the effect of organizational commitment on employee performance in the Tourism and Culture Office of East Kalimantan Province. The following are the hypotheses that we propose to achieve these goals, that is:

H1: Self-efficacy has a significant effect on organizational commitment.

H2: Self-efficacy has a significant effect on employee performance.

H3: Organizational commitment has a significant effect on employee performance.

\section{Literature Review}

\subsection{Self-efficacy}

Self-efficacy is one of the most influential aspects of self-knowledge in everyday human life. This is because the self-efficacy that is owned influences the individual in determining the actions to be taken to achieve a goal including the estimation of various events to be faced. Self-efficacy is the belief that someone can control the situation and get positive results (Zulkosky, 2009).

Fitzgerald (1991) emphasizes that self-efficacy is a self-perception of how well one can function in certain situations. Self-efficacy is related to the belief that the self has the ability to perform the expected actions. Bandura (2006) divides indicators of self-efficacy, namely the feeling of being able to do a job, having better abilities, being happy with a challenging job, and job satisfaction.

\subsection{Organizational Commitment}

Vancouver \& Schmitt (1991) assess a strong commitment to the organization arising from individual interactions with the organization when there is an attractive alternative offer of a job or position for 
someone. Meanwhile, McShane \& Von Glinow (2008) explained that organizational commitment refers to employees' feelings of commitment related to their involvement in the organization.

Organizational commitment is a condition in which an employee side with a particular organization, its goals, and desires to maintain membership in that organization (Robbins \& Judge, 2013). This is also supported by Salovey \& Sluyter (1997) which divides the three dimensions separately into organizational commitment (affective commitment, emotional feelings for the organization, and belief in its values).

Organizational commitment has been identified as a critical factor in understanding and explaining employee work-related behavior (Mowday et al., 1982). Great belief in the goals and values of the organization is aligned with the desire to put a lot of effort into the organization. A strong desire to maintain membership in the organization must be demonstrated by a strong commitment (Ilmi et al., 2021).

\subsection{Employee Performance}

Stoner (2004) informs that performance is a real behavior that is displayed by each person as a work achievement produced by employees in accordance with their role in the organization. With this reference, effective human resource management is closely related to the success of efforts to improve performance. Davis \& Newstorm (2011) pays attention to the individual elements which is one of the demands in the overall effort to improve performance.

Boon et al. (2019) divides the two components that affect a person's work performance or productivity. The first is the individual aspect which includes attitudes, characteristics, personality, traits physical, interest and motivation, experience, age, gender, education, and other individual factors. Second, situational factors consisting of physical, social, and organizational work that involve performance management. This process involves superiors, managers, and supervisors working together which aims to straighten employee performance so that it is aligned with organizational goals. This activity also determines their optimal performance in the long term (Ivancevich et al., 2008).

\subsection{Conceptual of Variables}

Figure 1 is a design of variables and dimensions in the variables of self-efficacy, organizational commitment, and employee performance that have their respective requirements. The parameters were adjusted according to the study objectives to answer the three hypotheses.

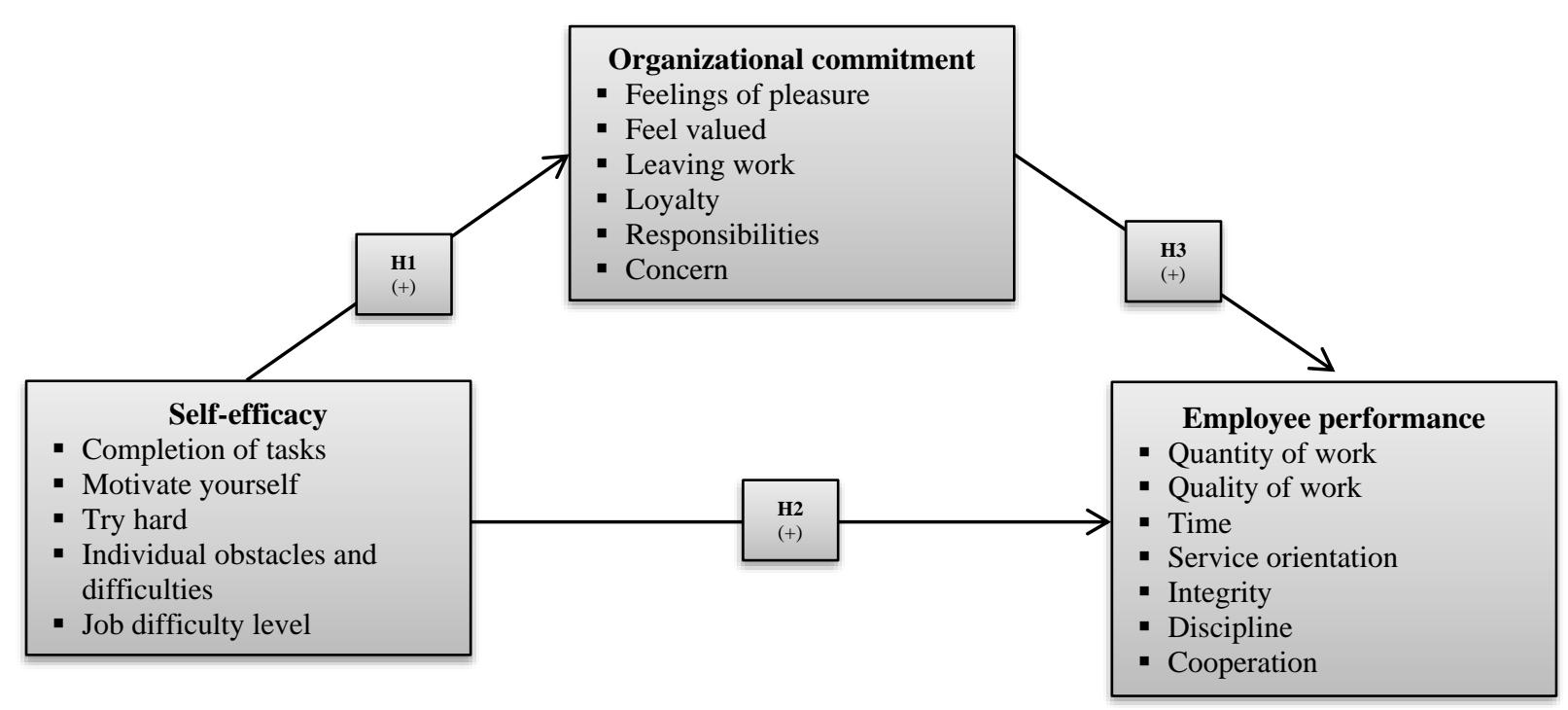

Figure 1: The proposed model and expected signs Source: Author's conceptualization 


\section{Methodology}

\subsection{Data and Measurements}

Hypothesis testing is supported by inferential statistical test tools that can produce or draw conclusions (Setini \& Darma, 2019). This study is also confirmative because it is necessary to conduct a series to test the conceptual model of theoretical and empirical variables because of the possibility to develop indicators and variables regarding social behavior in organizations (e.g. Ilmi et al., 2020). Thus, a planned study will be able to provide more complete and clearer information about the relationship between self-efficacy, organizational commitment, and employee performance. The criteria for each of these variables are explained based on the hypothesis. The first hypothesis and the second hypothesis, self-efficacy as an independent variable that affects organizational commitment and employee performance (dependent variable). In the second hypothesis, it will be described the extent to which the influence of organizational commitment (representing the variables) independent of employee performance. From this, it will be clear that employee performance will not play a role in the dependent variable or predict self-efficacy and organizational commitment. More details from Table 1 demonstrate the code and details on the three variables.

Table no. 1: Components and explanation

\begin{tabular}{|l|l|}
\hline Variables and indicators & Symbol \\
\hline Self-efficacy & $X 1$ \\
Completion of tasks & $\mathrm{X} 1.1$ \\
Motivate yourself & $\mathrm{X} 1.2$ \\
Try hard & $\mathrm{X} 1.3$ \\
Individual obstacles and difficulties & $\mathrm{X} 1.4$ \\
Job difficulty level & $\mathrm{X} 1.5$ \\
\hline Organizational Commitment & $\mathrm{Y} 1$ \\
Feelings of pleasure & $\mathrm{Y} 1.1$ \\
Feel valued & $\mathrm{Y} 1.2$ \\
Leaving work & $\mathrm{Y} 1.3$ \\
Loyalty & $\mathrm{Y} 1.4$ \\
Responsibilities & $\mathrm{Y} 1.5$ \\
Concern & $\mathrm{Y} 1.6$ \\
\hline Employee performance & $Y 2$ \\
Quantity of work & $\mathrm{Y} 2.1$ \\
Quality of work & $\mathrm{Y} 2.2$ \\
Time & $\mathrm{Y} 2.3$ \\
Service orientation & $\mathrm{Y} 2.4$ \\
Integrity & $\mathrm{Y} 2.5$ \\
Discipline & $\mathrm{Y} 2.6$ \\
Cooperation & $\mathrm{Y} 2.7$ \\
\hline
\end{tabular}

Source: Author's conceptualization

Types of data that are supported by primary data are quantitative or numerical data as a result of questionnaire scoring. The questionnaire was submitted to the informant unit with closed questions that measure attitudes from a negative state to a positive level (Kasuma et al., 2020). Used to obtain data on a number of dimensions of the variables analyzed through five alternatives to measure the attitudes of informants. The primary data in question is obtained directly from the object under study and for the purposes of the study concerned by involving employees in the Tourism and Culture Office of East Kalimantan Province. The survey is carried out in stages by asking questions related to indicators in predetermined variables.

\subsection{Sample}

The sample for this study is based on the census method through saturated sampling terms as a technique that uses all members of the population (Maria et al., 2019). Referring to this, the characteristics of the right sample area unit informants represented by 100 employees in the Tourism and Culture Office of 
East Kalimantan Province. Hiong et al. (2020) emphasize the sample size using the Structural Equation Modeling (SEM) technique of at least 100 samples. Meanwhile, Latan et al. (2020) also emphasized that for a similar technique, the sample size was between 100 and 200, so we used a minimum sample limit.

Table no. 2: Informant demographics

\begin{tabular}{|l|l|l|}
\hline Characteristics & Employees & Percentage \\
\hline Gender & & \\
Man & 72 & $72 \%$ \\
Female & 28 & $28 \%$ \\
Total & 100 & $100 \%$ \\
\hline Age & & \\
<40 years & 35 & $35 \%$ \\
40 years - 50 years & 40 & $40 \%$ \\
$>50$ years & 25 & $25 \%$ \\
Total & 100 & $100 \%$ \\
\hline Education & 3 & \\
Senior High School & 5 & $3 \%$ \\
Diploma & 62 & $5 \%$ \\
Bachelor & 30 & $62 \%$ \\
Master & 0 & $30 \%$ \\
Doctor & 100 & $0 \%$ \\
Total & & $100 \%$ \\
\hline Years of service & 25 & \\
<5 years & 62 & $25 \%$ \\
10 years - 20 years & 13 & $62 \%$ \\
> 20 years & 100 & $13 \%$ \\
Total & & $100 \%$ \\
\hline
\end{tabular}

Source: Author's survey

It can be seen that the informant unit is dominated by men as much as $72 \%$ and the rest are female, namely $28 \%$. Based on age, generally at the age of 40 years to 50 years it is $40 \%$ with the highest level of education is a bachelor as much as $62 \%$ and none of the employees have ever taken or completed studies at the Doctoral level. Table 2 also summarizes the characteristics of employees based on tenure, where they have been experienced because they have served in the Tourism and Culture Office of East Kalimantan Province for 10 years to 20 years.

\subsection{Parameters}

Specifications in describing data analysis are obtained by using the Structural Equation MedellingPartial Least Square (SEM-PLS) technique which is a multivariate statistic by comparing multiple dependent variables and multiple independent variables (Henseler et al., 2016). PLS is a variant-based SEM method designed to solve multiple regression when specific problems occur in the data by considering the small and small sample size (Hair et al., 2014).

The SEM-PLS technique is tailored to the needs of this study, so we divide it into two stages, namely the structural model (inner model), the measurement model (outer model), and hypothesis testing (Ringle et al., 2018). The outer model includes several steps such as testing construct validity and instrument reliability, while the inner model is supported by the level of change of variation (R2), path coefficient, convergent validity, discriminant validity, and composite reliability (Geisser, 1975; Stone, 1974). There is a normality assumption test that must be met for the model. Fulfillment of the data normality test is intended to investigate whether or not the distribution of each variable is normal (Ghozali, 2011). Finally, it is necessary to test the hypothesis in confirming conclusions with the following conditions:

$$
\begin{aligned}
& \text { Ho: } \gamma i=0 \text { (no effect); X against } Y \rightarrow \text { not significant } \\
& \text { Ha: } \gamma i \neq 0 \text { (influential); } X \text { to } Y \rightarrow \text { significant } \\
& \text { Ho: } \beta i=0 \text { opponent } \\
& \text { Ha: } \beta i \neq 0
\end{aligned}
$$




\section{Results}

Loading factor $>0.50$ is highly recommended, our findings using the pre-elimination model show that the Y1.1 indicator and Y1.5 indicator have a value of $<0.50$, which is 0.2420 .490 respectively so that these indicators are eliminated (see Figure 2).

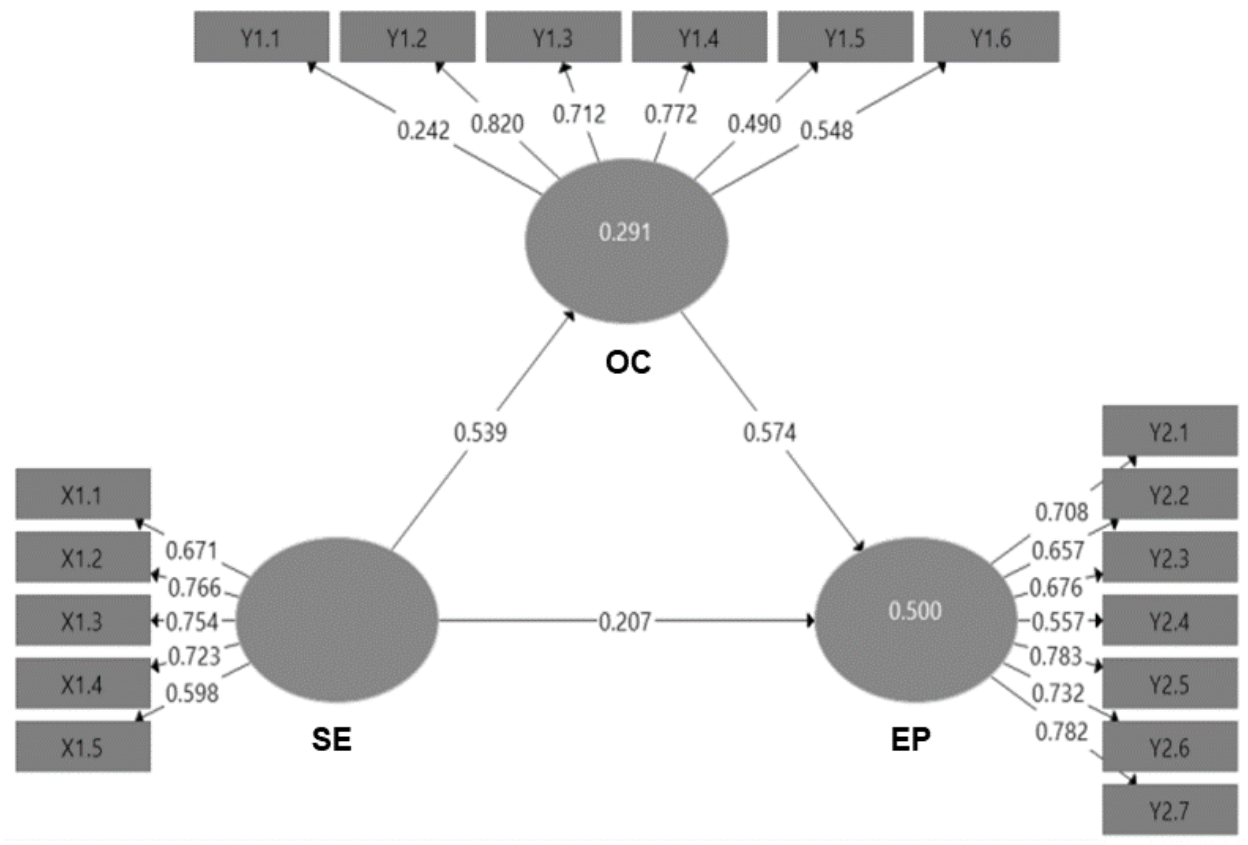

Fig. no. 2: Model before elimination

Source: Author's calculating

Meanwhile, Figure 3 presents the post-elimination model, the result is that the loading factor value for all indicators more than 0.50 so that it meets the proposed criteria in the inner structural and outer structural structures. We also found a loading factor above 0.50 through the Original Sample Estimate (OSE) on the indicator that had a dominant influence on each variable. The dominant indicator that has an influence on self-efficacy is indicator X1.2 with a gain of 0.778 . Meanwhile, the indicator that has a dominant influence on organizational commitment is the Y1.2 indicator, where the loading factor reaches 0.843 . On employee performance, the most dominant indicator is Y2.7 with a contribution of 0.782 .

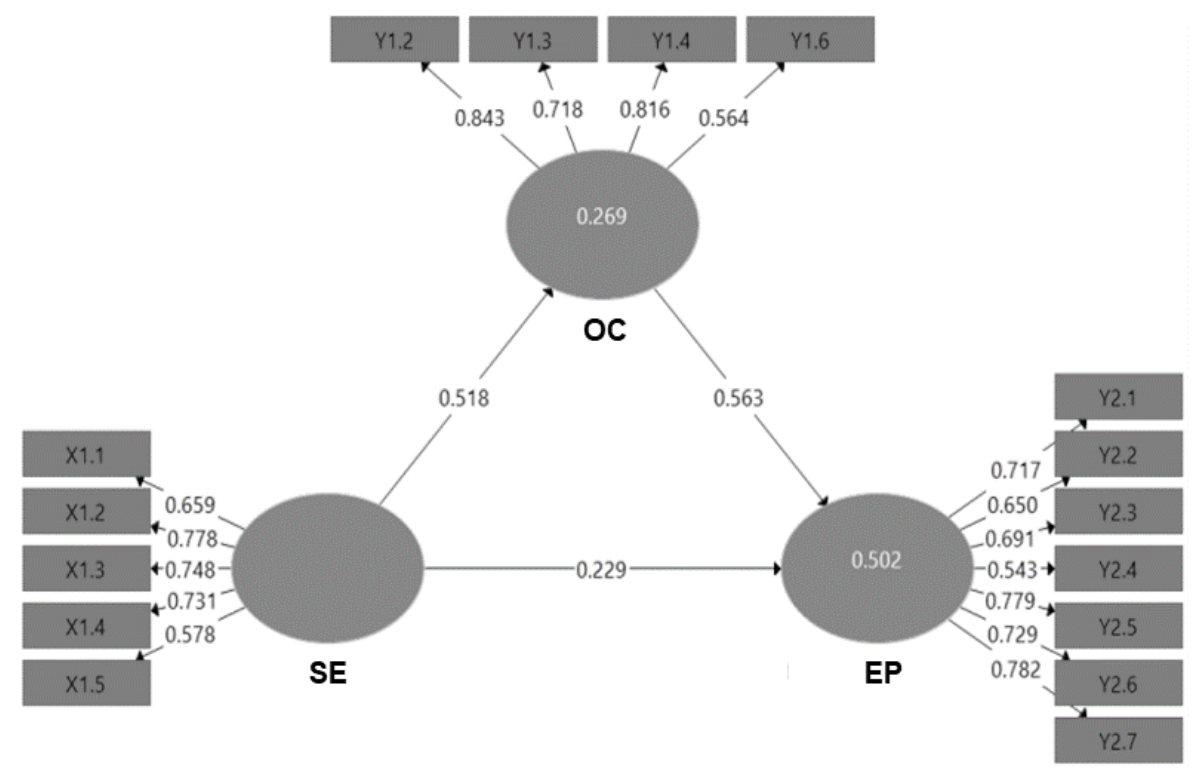

Fig. no 3: Model after elimination

Source: Author's calculating 
The next session is to find out which variables can be said to be "valid discriminant", measured by means of Average Variance Extracted (AVE). A construct with good validity, of course, is required with an AVE value that must be higher than 0.50. If AVE>0.50, it means that the variable instrument is valid (Hair et al., 2020). Table 3 describes the acquisition of AVE and the square root of AVE $(\sqrt{ } A V E)$. A construct is compared with the correlation value between other constructs, so we conclude that the value is higher than the correlation between other constructs, so that the instrument has met the conditions.

Table no. 3: Summary of AVE and AVE roots

\begin{tabular}{|l|l|l|l|}
\hline Variables & AVE & $\sqrt{A V E}$ & Decisions \\
\hline SE & 0.494 & 0.703 & Valid \\
\hline OC & 0.553 & 0.744 & Valid \\
\hline EP & 0.494 & 0.703 & Valid \\
\hline
\end{tabular}

Source: Author's calculating

To determine the reliability of constructs on variables, it can be traced based on composite reliability. A reliable construct, if the $\mathrm{CR}$ value is above 0.70 . As a complete model assumption, it is necessary to check the R-square value (Asih et al., 2020). Table 4 displays the two requirements.

The output shows if all constructs on the variable self-efficacy, organizational commitment, and employee performance are reliable, where the cronbach reliability $(\mathrm{CR})$ value $>0.70$. Then, the goodness of fit model interprets that the organizational commitment variation model is determined by self-efficacy of $26.90 \%$ and the phenomenon not explained in this model reaches $73.10 \%$. Variations in employee performance are also explained by self-efficacy and organizational commitment of $50.2 \%$, while there are $49.8 \%$ other variables outside the study model.

Table no. 4: Estimates for CR and R2

\begin{tabular}{|l|l|l|}
\hline Variables & CR & R2 \\
\hline SE & 0.828 & 0.269 \\
\hline OC & 0.829 & 0.502 \\
\hline EP & 0.871 & \\
\hline
\end{tabular}

Source: Author's calculating

The last session is the presentation of the Smart-PLS software to measure the test partially in each path. With the t-test, it can be seen the effect and probability level on these variables, where if the t-statistic > 1.96, it means that there is a significant relationship between the two variables, on the contrary, if the t-statistic $<1.96$ then there is no significant relationship between the two variables (Chin \& Newsted, 1999).

Table no. 5: Projections against CR

\begin{tabular}{|l|l|}
\hline Variables & CR-kutosis \\
\hline SE & 13.927 \\
\hline OC & 11.758 \\
\hline EP & 12.014 \\
\hline
\end{tabular}

Source: Author's calculating

In PLS-SEM, Sarwono (2015) actually does not require to follow the assumption of normality, because it does not treat covariance-based observation data. The normality of the data in this study can be described based on the acquisition of the critical ratio (CR) for kurtosis. The data is said to be multivariate normal if the multivariate CR-kurtosis value is> 3 with a probability level of $5 \%$ and vice versa. As a result, obtaining data on elf-efficacy, organizational commitment, and employee performance avoids symptoms of normality or has fulfilled the predetermined assumptions. 
Table no. 6: Results for inner weights

\begin{tabular}{|l|l|l|l|l|l|}
\hline Hypothesis & Relationship & OSE & P-value & T-statistics & Decisions \\
\hline H1 & SE $\rightarrow$ OC & 0.518 & 0.000 & 6.929 & Accepted \\
\hline H2 & SE $\rightarrow$ EP & 0.229 & 0.016 & 2.425 & Accepted \\
\hline H3 & OC $\rightarrow$ EP & 0.563 & 0.000 & 7.623 & Accepted \\
\hline
\end{tabular}

Source: Author's calculating

Self-efficacy has a positive and significant effect on organizational commitment and employee performance. In addition, organizational commitment also has a positive and significant effect on employee performance. The overall performance for OSE is positive and the partial value determined by the t-statistic is higher than 1.96, so the result is significant (see Table 6).

\section{Discussions}

Self-efficacy has a significant effect on organizational commitment. This indicates that self-efficacy, as measured by self-motivating indicators (X1.2), has led to increased organizational commitment as measured by indicators of feeling valued (Y1.2) in the Tourism and Culture Office of East Kalimantan Province.

Organizational commitment is a psychological contract between employees and agencies. The psychological contract referred to here is an unwritten agreement that defines what the agency wants with employees and vice versa (Khan, 2017). If they fail to obtain a psychological contract, it will result in a dysfunctional conflict which will reduce organizational commitment and can have an impact on role conflict in members if the results expected by the agency through task completion for members are not resolved properly.

Self-efficacy also has a significant effect on employee performance. This indicates that self-efficacy, as measured by self-motivating indicators (X1.2), has led to an increase in employee performance as measured by cooperation indicators (Y2.7) in the Tourism and Culture Office of East Kalimantan Province.

Self-efficacy is a belief that arises because you have confidence in your ability to carry out a job. This belief is related to the motivation that employees have to be more confident and have confidence in their own abilities. Self-efficacy is needed in them by increasing the ability to do the tasks given so that the agency runs optimally and their performance can be maximized (Lisbona et al., 2018). Self-efficacy is needed to make employees work optimally and have a high work ethic.

Organizational commitment has had a real impact on employee performance. This indicates that organizational commitment as measured by the indicator of feeling valued (Y1.2) has led to increased employee performance as measured by the indicator of cooperation (Y2.7) in the Tourism and Culture Office of East Kalimantan Province.

The phenomenon that often appears today is the limited achievement of agency missions caused by the low achievement of work completion targets because it generally refers to the quantity of employee attendance. This clearly indicates the lack of organizational commitment that employees have in terms of quality. Those with high organizational commitment have different attitudes and concerns compared to those with low commitments (If organizational commitment increases, it can result in work performance and level of achievement of employee work targets that are in accordance with standards (Qureshi et al., 2019).

\section{Conclusions and Recommendations}

This study determines that the three proposed hypotheses can be accepted. The first hypothesis is known that self-efficacy significantly affects organizational commitment. The second hypothesis concludes that self-efficacy also has a significant effect on employee performance. The third hypothesis highlights that there is a significant influence between organizational commitment and employee performance. This means that improved self-efficacy can encourage increased organizational commitment and employee performance in the Tourism and Culture Office of East Kalimantan Province. Organizational 
commitment also plays an important role in increasing the performance of employees in the Tourism and Culture Office of East Kalimantan Province explicitly.

The policy implication rests on the practical and empirical side that requires improvement through employees in the Tourism and Culture Office of East Kalimantan Province to maintain their belief in motivating themselves to take appropriate actions so that they feel part of their work. Those who have the confidence and ability to complete tasks still feel comfortable with conditions that require cooperation. Organizational commitment is not only limited to survival or not in the workplace, but there must be a sense of care and awareness that they are working for the state and as public servants so that they are required to always show optimal performance.

In future studies, it should be necessary to develop patterns that are relevant to human resources, especially related to organizational commitment and employee performance. Overall discussion can be applied to similar objects and provide the depth of material so that similar studies are more varied.

\section{References}

Asih, D., Setini, M., Soelton, M., Muna, N., Putra, I., Darma, D. \& Judiarni, J., 2020. Predicting green product consumption using theory of planned behavior and reasoned action. Management Science Letters, 10(14), 3367-3374.

Bandura, A., 2006. Self-efficacy mechanism in psychological and health promoting behavior. Prentice Hall, New Jersey.

Boon, C., Den Hartog, D.N. \& Lepak, D.P., 2019. A Systematic review of human resource management systems and their measurement. Journal of Management, 45(6), 2498-2537.

Chin, W.W. \& Newsted, P.R., 1999. Structural equation modeling analysis with small samples using partial least squares. In R. H. Hoyle (Ed.), Statistical strategies for small sample research (pp. 307-341). Sage Publications, Thousand Oaks: CA.

Darma, D.C., Purwadi, P., Sundari, I., Hakim, Y.P. \& Pusriadi, T., 2020. Job characteristics, individual characteristics, affective commitments and employee performance. Research and Review: Human Resource and Labour Management, 10(1), 7-18.

Davis, K. \& Newstor, J.W., 2011. Organizational behaviour: Human behaviour at work. Mc-Graw Hill, New York.

Dinc, M.S., 2017. Organizational commitment components and job performance: mediating role of job satisfaction. Pakistan Journal of Commerce and Social Sciences, 11(3), 773-789.

Faradila, N., Heksarini, A. \& Darma, D.C., 2020. Antecedents that affect job satisfaction and employee performance. Saudi Journal of Business and Management Studies, 5(6), 293-302.

Fitzgerald, T.K., 1991. Media and changing metaphors of ethnicity and identity. Media, Culture \& Society, 13(2), 193-214.

Geisser, S., 1975. The predictive sample reuse method with applications. Journal of the American Statistical Association, 70(350), 320-328.

Ghozali, I., 2011. Aplikasi analisis multivariate dengan program SPSS [In English: Multivariate analysis application with SPSS program]. Badan Penerbit Universitas Diponegoro, Semarang.

Hair, J.F., Sarstedt, M., Hopkins, L. \& Kuppelwieser, G.V., 2014. Partial least squares structural equation modeling (PLS-SEM). European Business Review, 26(2), 106-121.

Hair, J.F., Howard, M.C. \& Nitzl, C., 2020. Assessing measurement model quality in PLS-SEM using confirmatory composite analysis. Journal of Business Research, 109, 101-110.

Henseler, J., Hubona, G. \& Ray, P.A., 2016. Using PLS path modeling in new technology research: updated guidelines. Industrial Management \& Data Systems, 116(1), 2-20.

Hiong, L.S., Ferdinand, A.T. \& Listiana, E., 2020. Techno-resonance innovation capability for enhancing marketing performance: a perspective of RA-theory. Business: Theory and Practice, 21(1), 329-339.

Ilmi, Z., Darma, D.C. \& Wijayanti, T.C., 2020. Can servqual mediate from the store atmosphere and customer satisfaction?. Management Theory and Studies for Rural Business and Infrastructure Development, 42(3), 359-368.

Ilmi, Z., Robiansyah, R., Hadjaat, M., Zainurossalamia, S. \& Darma, D.C., 2021. Determinants of leadership and organizational culture in implementing business strategies. SEISENSE Business Review, 1(1), 10-17.

Issa, A., 2016. Corporate governance and social responsibility. Cactus Tourism Journal, 14(2), 45-51.

Ivancevich, J.M., Konopaske, R. \& Matteson, M.T. (2008). Organizational behavior and management, 8th ed. McGraw-Hill/Irwin, Boston. 
Kasuma, J., Razak, F.L., Omar, N., Naim, A.S., Naimullah, B.S. \& Darma, D.C., 2020. Attitude, perceived usefulness and perceived ease of use towards intention to use m-commerce: a case of Grocery Shoppers in Kuching, Sarawak. Journal of Entrepreneurship and Business, 8(1), 71-84.

Khan, M.A., 2017. The moderation effect of teaching-experience on the relationship between self-efficacy and organizational commitment. International Journal of Research in Management, Economics and Commerce, 7(12), 45-49.

Latan, H., Jabbour, C. J. \& Jabbour, A.B., 2019. Whistleblowing triangle': Framework and empirical evidence. Journal of Business Ethics, 160, 189-204.

Lisbona, A., Palaci, F., Salanova, M. \& Frese, M., 2018. The effects of work engagement and self-efficacy on personal initiative and performance. Psicothema, 30(1), 89-96.

Maria, S., Pusriadi, T., Hakim, Y.P. \& Darma, D.C., 2019. The effect of social media marketing, word of mouth, and effectiveness of advertising on brand awareness and intention to buy. Jurnal Manajemen Indonesia, 19(2), 107-122.

Maria, S., Darma, D.C. \& Setyawan, H., 2020. PLS-SEM to predict the relationship between procedural justice, organizational commitment, OCB, and job satisfaction. Journal of Wellbeing Management and Applied Psychology, 3(3), 1-13.

Mayer, J.D. \& Salovey, P., 2007. Emotional development and emotional intelligence: education and implications. Basic Books, New York.

McShane, S.L. \& Von Glinow, M.A., 2008. Organizational behavior: emerging realities for the workplace revolution, 4th edition. McGraw-Hill/Irwin, New York.

Mowday, R., Porter, L. \& Steers, R., 1982. Employee-organization linkages: the psychology of commitment, absenteeism, and turnover. Academic Press, New York.

Purwadi, P., Darma, D.C., Febrianti, W. \& Mirwansyah, D., 2020. Exploration of leadership, organizational culture, job satisfaction, and employee performance. Technium Social Sciences Journal, 6(1), 116-130.

Qureshi, M.A., Qureshi, J.A., Thebo, J.A., Shaikh, G.M., Brohi, N.A. \& Qaiser, S., 2019. The nexus of employee's commitment, job satisfaction, and job performance: an analysis of FMCG industries of Pakistan. Cogent Business \& Management, 6(1), 1-23.

Ringle, C.M., Sarstedt, M., Mitchell, R. \& Gudergan, S.P., 2018. Partial least squares structural equation modeling in HRM research. The International Journal of Human Resource Management, 31(12), 1-27.

Robbins, S.P. \& Judge, T.A., 2013. Organisational behavior, 15th edition. Pearson, Boston.

Salovey, P. \& Sluyter, D.J., 1997. Emotional development and emotional intelligence: educational implications (Eds.). Basic Books, New York.

Sarinah, S., Akbar, M. \& Prasadja, R., 2018. The effect of work autonomy, self-efficacy and work engagement towards organizational commitment. International Journal of Economics, Commerce and Management, $6(2), 31-44$

Sarwono, J., 2015. Membuat Tesis dan Disertasi dengan Partial Least Square SEM (PLS-SEM) [Making Thesis, Thesis, and Dissertation with Partial Least Square SEM (PLS-SEM)]. Andi, Yogyakarta.

Setini, M. \& Darma, D.C. (2019). Towards market share: segmentation, target and market position. International Business Management, 13(9), 405-414.

Stone, M., 1974. Cross-validatory choice and assessment of statistical prediction (with discussion). Journal of the Royal Statistical Society, 36(2), 111-147.

Stoner, J.A., Freeman, R.E. \& Gilbert, D.R., 2004. Management, 6th edition. Pearson Education, Tamil Nadu.

Vancouver, J.B. \& Schmitt, N.W. (1991). An exploratory examination of person-organization fit: organizational goal congruence. Personnel Psychology, 44(2), 333-352.

Wijayanti, T.C., Setini, M., Darma, D.C., Purwadi, P. \& Alka, P.R., 2020. Connectivity continuous improvement program and employee performance. International Review of Management and Marketing, 10(1), 54-62.

Yokoyama S. (2019). Academic self-efficacy and academic performance in online learning: a mini review. Frontiers in Psychology, 9(2794), 1-4.

Zainurossalamia, S., Darma, D.C., Kasuma, J., Ratnasari, S.L. \& Tasenţe. T., 2020. Apparatus performance as mediation of creativity and innovation towards the successful application of e-Kelurahan. European Journal of Human Resource Management Studies, 4(2), 108-126.

Zeb, M.S. \& Nawaz, A., 2016. Impacts of self-efficacy on organizational commitment of academicians a case of Gomal University. Journal of Information \& Knowledge Management, 6(1), 36-42.

Zulkosky, K., 2009. Self-efficacy: a concept analysis. Nursing Forum, 44(2), 93-102. 